技

術

いたが，それらもその 1 日後には全て死隇した。雌成ダ 二は宿主に奇生した状態では通常 $3 \sim 4$ 週間生存すると いわれる3.

本ダニの感染率は若齢の動物で高いとされているが 1), 今回の 2 症例は 7 才齢と 10 才秢でむしろ高齢の部 類に入るものであった． 藤ら $(1976)^{5)}$ は, このダ $=の$ 感染は年齢に関係なく起こるが，若齢猫の場合に症状が 重くなる傾向があると述べている.

治療は今回の場合，2硫化セレニウムによる薬浴とク ロタミトンの外用を主体に行なったが，副作用もなく著 しい治療効果を得た。

治療に際しては人体への感染に注意を払う必要があ る. しかし患猫に接した全ての人に皮膚症状があらわれ る訳ではなく，体質によりその変状の発現が左右される よらである、ちなみに今回の症例の治療には 3 人の獣医 師が当たったが，そのうちの 1 人の前腕部に軽度の搔㾕 感を伴った小紅疹を認めた以外は全く異常を認めなかっ た.このネコショウセンコウヒゼンダニが人体から㭘出 されたという古い報告もあるというが2)，今回の例を含
講 坐

めほとんどの報告では人から本ダニは検出されていな W.

人の治療については人医に委祇るのが良いが，ベータ ーメサゾン, $\alpha$-マレイン酸クロールフェニラミンの複合 剤 (七レスタミンR)内服执よびクロタミトン外用剤が効 果あるといら²).

近年, ペットの屋内飼育の増加に伴って, 人畜共通感 染症の問題が重視されるようになった. ダ二症もその代 表的疾患の一つであるが，獣医学領域での関心はまだ薄 い. 今後の資料集積が望まれるところである.

本症例猫の紹介をいただいた，飯沢 真，田所隆治両 先生に括礼申し上げる.

$$
\text { 参考 文 献 }
$$

1) FLYNN, R. J. : Parasites of laboratory animals, 454, Ames, Iowa State Univ. Press (1973).

2) 初鹿 了, 三好 薰, 清水泉太: 衛生動物, 30, 81 (1979).

3) 迫悟: 獣医臨床寄生虫病学, 獣医臨床寄生虫 学編集委員会編, 473～475, 東京, 文永堂 (1979).

4) 藤 幸治, 森本隆芳：衛生動物，27, 81 (1976).

\title{
動物用ワクチンの概要とその正しい使い方 (VII)
}

7. 豚ボルデテラ感染症ワクチン

$$
\text { 瀬 戸 健 次* }
$$

\section{1. 豚萎縮性鼻炎の現状と予防注射}

豚萎縮性鼻炎 Atrophic rhinitis（AR） は哺乳期の子 豚が Bordetella bronchiseptica (Bb) の感染を受け, 鼻腔 内で菌が増殖し, 鼻粘膜の慢性炎症から鼻甲介および上 顎骨の萎縮・変形をきたし, はなはだしいものでは顔面 の萎縮, いわゆる独面, 1 側がとくに萎縮したものでは 鼻曲りとして認められる慢性の伝染病である. 外観上全 く異常が認められないものでも, 剖検で鼻に著しい病変 があるものが意外に多く, 屠場出荷豚の $70 \%$ 以上 A R 病変を認めたといら報告もある.

本病がわが国に侵入したのは，1953年アメリカから輸 入された種豚からで, 1966年以後には各地に広がり, 現 在では全国的に濃厚な污染が認められているが，本病は 届出を要する伝染性疾病に指定されていないため, 詳細 な統計資料はない。

本病に罹患しても，それだけで死亡することは汪とん

* 農林水産省動物医薬品検査所（東京都国分寺市戸倉 1-15-1)

日獣会誌 $33 \quad 279 \sim 281 \quad(1980)$
どないが, 増体率の 低下, 飼料要求率の増大, 衛生経 費, 豚舎の回転率などの悪化による経済的被害が大き い. また, 豚流行性肺炎（SEP）の感染率を高めたり， その重篤化や, パラッレラ, ヘモフィルスなどの 2 次感 染を受けやすくするとも考えられている.

感染は保菌豚のクシャミによる鼻汁飛洙の吸入, 鼻端 間の接触のほか，污染壁面などからの間接接触によって も起こる. 発症がみられるのは哺乳期に感染したとき最 も多く, とくに生後 1 週以内に感染するとほとんどすべ て鼻甲介のはげしい萎縮がみられるが， 6 週を過ぎると 感染してもほとんど病変を形成しなくなる.

はじめにみられる 症状は鼻粘膜の 炎症に伴らクシャ ミと鼻づまりで, 早いものは 1 週舲ですでにみられる. 鼻汁は水様から粘稠, さらに膿性となる。炎症の結果, 鼻腔の涙管開口部が詰まり，涙が流れる，涙も次第に 粘稠性を増し，それに泥や塺埃が付着し，眼下に三日 月形のいわゆる eye patchが形成されるようになる，鼻 甲介の損傷が進むと鼻汁に血液塊を混じるよらになり， 呼吸は荒く，とさに激しい鼻出血をみることがある，鼻 
技 術

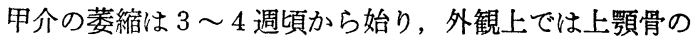
発育不良による前歯の晈合不整として認められる。 2 力 月齢位になると萎縮が進み，鼻後方の皮虐が縮んで㳷が 寄ってくるよらになる. 顔面の骨も変形し， 1 側の鼻甲 介が強く侵されたときには鼻端がその方向を向いたいわ ゆる鼻曲り，両側ともに侵されたときは顔面の短縮， 拉よび径の縮少によっていわゆる狆面を呈するようにな る.

病変は軽度の肺炎が認められることがある以外は, 鼻 腔周辺とくに鼻甲介に限局され，鼻粘膜の充血，多量の 出物，鼻甲介の萎縮（下鼻甲介に多く，上鼻甲介から とさには穊骨に及ぶ）拉よび融解, 欠損などが特徵的で ある、鼻腔の直径は短かくなり, 鼻中隔の弯曲も認めら れる。

しかし，鼻甲介が帛とんどなくなっているくらい強く 侵されていても，外観上全く正常と変わらないものもあ る.

$B b$ 菌は萊膜 $(\mathrm{K})$ 抗原と壞死毒素とをもつ I 相菌か ら, これらを欠く III相菌へ変異するが, 病原性があるの はI相菌に限られる。

鼻腔内に侵入した菌は, 定着・増殖して病変を形成す るが，一般に 4 カ月齢ぐらいから菌数は次第に減少す る.しかし，成熟後にも保菌しているものがかなり認め られておりこれらが感染源となっている.

本菌の分離には，これまで $1 \%$ にブドウ糖を添加した MacConkey 培地や，それにフラルタドンとクリス タルバイオレットを加えた Farrington \& Switzerの D-20 培地, $1 \%$ ブドウ糖加 DHL 培地などが使われて きたが, 1979 年に発表された Smith \& Baskerville の G20G培地では雑菌のover growth がほとんどなく, ま た $B b$ に対する発育阻害剤の影響がなく，ほぼ純培養 状に $B b$ が分離でき，検出率はかなり向上するといわ れる。

血清学的診断法としては, $B b$ I 相菌をホルマリンとチ メロサールとで死菌とした凝集反応用抗原が市販されて おり，これを用いた急速および試験管凝集反応が行なわ れている. 自然感染豚の血清抗体価は, 早いものでは感 染後 1 週で, 遅いものでは $1 \sim 3$ カ月後に上昇するが, 一般にその価は低いものが多い。

菌分離あるいは血清反応によって感染の有無, 污染状 態を知ることはできるが，病変の有無およびその程度と は必らずしも一致しないことに注意する必要がある.

本病の予防の目的にサルファ剂, カナマイシン, ペニ シリン，テトラサイクリンなどの長期投与が行なわれて きたが，飼料安全法の施行により制限が 加えられ，い っぽうこれらの薬剤に対する抵抗性菌とくにR因子によ る耐性菌が広く分布し, 本菌の駆逐が因難となってき た.
講來

そこで，本病に対するワクチンの開発が精力的に進め られ, 中瀬らにより子豚免疫法, 興水らによる母豚免疫 法による発病防御が相次いで報告された。それらの成 績から，1973年に子豚免疫法のためのワクチンが， 1975 年に母豚免疫用のワクチシがそれぞれ製造承認をらけ， 2 社に拈いて製造されるようになった。 これらのワクチ ンは製法の違いはあるが，いずれも $B b$ I相菌をホルマ リンで不活化し, 水酸化アルミニウムゲルに吸着させた ものであり，本質的な差は認められず，いっぽら子豚免 疫法，母豚免疫法それぞれの欠点を補い，長所を生かす 必要性から，1979年に至り，両社にワクチンを子豚・母 豚のいずれにも使用できるように製造承認事項の変更が 行なわれた。

ワクチンの製造量は著しい増加を見せ，1975年には約 200 万 $\mathrm{m} l$ であったものが, 1978 年には 700 万 $\mathrm{m} l$ を超 え, 1979 年度では現在 (1980 年 2 月) すでに約 900 万 $\mathrm{m} l$ に達している.

いっぽら，海外においても同じような死菌ワクチンの 研究が続けられ, 近年に至ってアメリカ, ドイッ, フラ ンスなどで実用化されるように至っている。

\section{2. 豚ボルデテラ感染症ワクチンの概要}

前述のごとく，わが国に和いては 2 力所の製造所でそ れぞれワクチンが生産されている，両社と和ける製造方 式は異なり, いっぽうは Bordet-Gengou 培地で $37^{\circ} \mathrm{C}$ 24 時間培養した $B b$ L3-72 株を, リン酸緩衝食塩液 (PBS) で洗い落し，1回 PBS で遠心洗浄後, ホルマリ ンを $0.25 \%$ の割合に加えて殺菌し，菌液の濃度を 1.2 $\times 10^{11} / \mathrm{ml}$ に調整したのち, 水酸化アルミニウムゲルを 等量に加え, チメロサールを $0.01 \%$ の割合に添加した ものである.

他は, $B b \mathrm{~N}-40$ 株を培養 タンク内で通気攪䢁培養し た菌液に，ホルマリンを $0.25 \%$ の割合に加えて殺菌 し, 水酸化アルミニウムゲルを適量加えたのち, 菌量が $1 \times 10^{10} / \mathrm{ml}$ 以上になるよらに調整し，チメロサールを $0.01 \%$ 割合に加えたものである.

これらのワクチンは，それぞれの製造所に特いて自家 検査を行ない, 合格したものについて薬事監視員によっ て無作意的に収去・封印されて動物医薬品検查所に送付 され，国家検査をらける。

自家検查および国家検查は，特性試験，無菌試験，純 粋試験, 安全試験, 力価試験, 防腐剂含有量試験の各項 目について行なわれ，そのすべてに合格したものが市販 される。

ワクチンは灰白色あるいは淡黄灰色の液体で, 静置す れば透明な上清と底部の沈殿物とにわかれるが，振盪す れば均一な浮遊液となり, 異物や異臭がなく,かつ小分容 器ごとの内容はすべて均一でなければならない，液状チ 
技

術

オグリコール酸塩培地で発育する生菌を全く認めず，塗 抹染色標本に括いても $B b$ I 相の形態汪一致しない微生 物の混入を認めてはならない。

3 週龄（約 $10 \mathrm{~g} ）$ のマウスの大腿部筋肉内に $0.1 \mathrm{~m} l$ あ るいは皮下に $0.5 \mathrm{ml}$, モルモットの皮内に $0.1 \mathrm{ml}$ を注 射しても泀とんぞ異常を示さず，壊死毒素は不活化され ている。また，防腐剤の含有量は規定量以下でなければ ならない。

いっぽう，ワクチンを生理食塩液で10倍に希釈し，30 匹の 3 週齡マウスに腹腔内注射し， 2 週間後 10 匹ずつ に強毒 $B b \mathrm{H} \mathrm{16-2}$ 株の $10^{9}, 10^{8}, 10^{7}$ 個を, 同数の対 照マウスには $10^{8}, 10^{7}, 10^{6}$ 個をそれぞれ腹腔内に注射 し, 両群の $\mathrm{LD}_{50}$ を算出して免疫効果を測定するとき, 免疫指数は 2 以上, すなわち免疫群は非免疫対照群にく らべ 100 倍以上の攻撃菌量付耐兄る。いっぽう1 カ月龄 未満の $B b$ 抗体陰性の子豚 2 頭に, 1 週間隔で $1 \mathrm{ml}$ と $2 \mathrm{~m} l$ とを筋肉内注射し，最初の注射時から 4 週間観察 しても異常を示さず, 観察期間終了時に非注射対照豚 1 頭とともに採血して凝集抗体価を測定するとき，注射豚 は 2 頭とも 40 倍以上の抗体価を示し, 対照豚では抗体 価の上昇が認められないことを確認する。

\section{3. クチンの使用法}

ワクチンは $2 \sim 5{ }^{\circ} \mathrm{C}$ の冷暗所に保存し, 使用時には上 く振盪してから注射する。

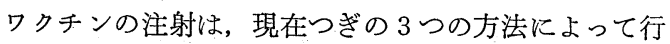
なわれている。すなわち，1） 子豚能動免度，2）母豚 免疫 $\rightarrow$ 子豚受動免疫，3） 母豚免疫十子豚能動免疫の各 免疫法である.

子豚能動免疫法は，非免疫母豚から産れた子豚に用い られる方法で，できるだけ早期から免疫を行なら必要が あり, 遅くとも生後 4 週秢以前に $1 \mathrm{ml}, 1$ 週後 $2 \mathrm{ml}$ を それぞれ筋肉内に注射する。

母豚免疫法は，母豚を免疫することによって産生され た抗体を，初乳を介して子豚に移行させ，発育初期の 感染から防御しょうとするものである. そのため, 分婏 時飞最高の抗体価が得られるようにワクチンの注射時期 を定める必要がある。このワクチンはアジュバントワク チンであり，免疫の間隔をある程度長くした漂らが， 2 回目の注射後における抗体価の上昇が良好であるため, 1 カ月以上の間隔で $10 \mathrm{~m} l$ ずつ 2 回筋肉内に注射する. 第 2 回の注射は分娩予定日の 1 カ月前に行ならようにす るように定められている. ただし, 次回以降の娃娠時で は, 分婏前 1 カ月の 1 回だけでよい.

母豚・子豚能動免疫法は, 子豚免疫法に拈ける早期の 免疫欠除, 母豚免疫法の移行抗体低下の欠点を補5目的 で行なわれる方法である，そのため，免疫母豚から産れ た子豚に, 生後 5 週目に $1 \mathrm{~m} l, 1$ 週打いて $2 \mathrm{~m} l$ 筋肉内
講座

飞注射するか， 6 週目に $5 \mathrm{~m} l$ を筋肉内に注射するかの いずれかによって免疫を行なう。

各地の家音保健衛生所や研究所で行なわれた試験によ れば, 現行の市販ワクチンで免度された母豚の抗体価 は, 分婏時で 1,280〜5, 120 倍の範围のものが多いよう であるが，なかには 640 倍以下のものる散見される。一 般に母豚の抗体価が $1,280 \sim 2,560$ 倍のとき，その子豚

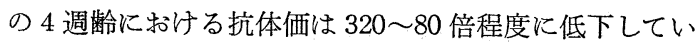
ることが多い。

野外飞批ける子豚能動免疫法, 母豚免疫法の評価は必 らずしも一定していない. ワクチンの発売以来, 各地の 家畜保健衛生所からその使用成績について多数の報告が 行なわれたが，その結果にはかなりの差がみられる。こ れは養豚場間に括ける $B b$ 污染度, 豚の免疫獲得に関す る遺伝形質の差，一般衛生管理の良否など，いろいろな 因子が関与していると考它られるが，全体としてみれば 非免疫対照との間に $B b$ 定着開始の遅延, 定着期間の短 縮, 症状あるいは病変の軽減, 增体率や飼料効率の向上 による経済性などで差が認められ，ワクチン注射の効果 が現われているょらに思われる。

現在ではこれらの免疫法に括ける空白期間を埋めるた め, 母・子能動免疫法が各地で行なわれるようになり， 従来の方法では免疫の効果がみられなかったような濃厚 污染養豚場でも免疫の有効性が認められるようになって きた。

この方法では, 母豚からの移行抗体が減少し, 凝集価 80〜160 倍となったものではワクチン注射による抗体価 の上昇が認められるが，640 倍以上の移行抗体価を示す ものではワクチンを注射しても抗体価の上昇はみられ ず，非注射のものと同様に抗体価の低下が続く．また移 行抗体価 320 倍のものではワクチン注射後抗体価の低落 が停止し，以後ほぼ同じ価が続くことが認められてい る.したがって子豚に対する補強注射時期の決定は慎重 に行なわなければならないだろう，とくに母豚の抗体価 が低かったり，抗体の移行が十分に行なわれないような 場合には, 子豚免度法に準じた免疫法を採用しなければ ならないことも考觉られる。そのためには抗体価，少な くとも母豚の抗体価は的確に把握して技かなければなら ないだろう。

いずれにしても，このワクチンは，豚コレラや豚丹毒 ワクチンなどのように, 強い免疫力による 防疫= 効果 を期待するような性質のものでなく, ある程度の感染は 許しても，病変の発現を抑制あるいは軽減し，“経済性 の向上こを期待する性質のものと考光られる．そのため には，一般衛生管理体勢の充実を伴わなければ，その真 価を発揮することは困難であるう。 